\title{
Developments in Modern Racecar Driver Crash Protection and Safety- Engineering Beyond Performance
}




\title{
Other SAE books of interest:
}

\author{
Lumbar Injury Biomechanics \\ By Jeffrey A. Pike \\ (Product Code: PT-153)
}

\section{Vehicle Accident Analysis and Reconstruction \\ Methods, Second Edition \\ By Raymond M. Brach and Matthew Brach}

(Product Code: R-397)

\author{
Occupant Protection and Automobile \\ Safety in the U.S. since 1900 \\ By Roger F. Wells \\ (Product Code: PT-404)
}

\author{
For more information or to order a book, contact: \\ SAE International \\ 400 Commonwealth Drive \\ Warrendale, PA 15096-0001 USA \\ Phone: 877-606-7323 (U.S. and Canada only) \\ or 724-776-4970 (outside U.S. and Canada) \\ Fax: 724-776-0790; \\ Email: CustomerService@sae.org; \\ Website: books.sae.org
}




\section{Developments in Modern Racecar Driver Crash Protection and Safety- Engineering Beyond Performance}

Edited by John W. Melvin and J. Kirk Russell

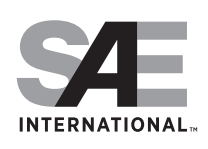




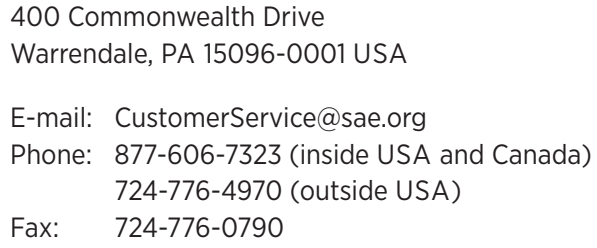

Copyright $\odot 2014$ SAE International. All rights reserved.

No part of this publication may be reproduced, stored in a retrieval system, distributed, or transmitted, in any form or by any means without the prior written permission of SAE International. For permission and licensing requests, contact SAE Permissions, 400 Commonwealth Drive, Warrendale, PA 15096-0001 USA; e-mail: copyright@sae.org; phone: 724-772-4028; fax: 724-772-9765.

ISBN 978-0-7680-8026-1

Library of Congress Catalog Number 2013946186

SAE Order Number PT-160

DOI 10.4271/PT-160

Information contained in this work has been obtained by SAE International from sources believed to be reliable. However, neither SAE International nor its authors guarantee the accuracy or completeness of any information published herein and neither SAE International nor its authors shall be responsible for any errors, omissions, or damages arising out of use of this information. This work is published with the understanding that SAE International and its authors are supplying information, but are not attempting to render engineering or other professional services. If such services are required, the assistance of an appropriate professional should be sought.

\section{To purchase bulk quantities, please contact}

SAE Customer Service

e-mail: CustomerService@sae.org

phone: 877-606-7323 (inside USA and Canada)

724-776-4970 (outside USA)

fax: 724-776-0790

Visit the SAE Bookstore at

books.sae.org 


\section{Dedication}

This compendium is dedicated to four individuals who were instrumental in the creation, development, and implementation of racing safety research:

Gary Dickinson (1938-2000)

John Pierce (1936-2009)

Steve Peterson (1950-2008)

Sid Watkins (1928-2012) 


\section{Table of Contents}

Acknowledgments

ix

Introduction ........................................................................................................................... 1

Technical Papers ................................................................................................................... 5

Biomechanical Performance of a New Head and Neck Support (902312)

Hubbard, R. P. and Begeman, P. C.

Racing Car Restraint System Frontal Crash Performance Testing (942482)

Melvin, J. W., Little, W. C., et al.

Development of the HANS Head and Neck Support for Formula One (983060)

Gramling, H., Hodgman, P., and Hubbard, R.

Biomechanical Analysis of Indy Race Car Crashes (983161)

Melvin, J. W., Baron, K. J., et al.

Barrier Testing (983061)

Wright, P., and Mellor, A.

Development and Field Performance of Indy Race Car Head Impact Padding (2001-22-0019) Melvin, J. W., Bock, H., et al.

Sled Test Evaluation of Racecar Head/Neck Restraints - Revisited (2004-01-3516)

Melvin, J. W., Begeman, P. C., and Foster, C. D.

Biomechanical Principles of Racecar Seat Design for Side Impact Protection (2004-01-3515) Melvin, J. W., and Gideon, T. W.

Race Car Nets for the Control of Neck Forces in Side Impacts (2004-01-3513)

Gideon, T. W., Melvin, J., and Begeman, P.

Initial In-Service Performance Evaluation of the SAFER Racetrack Barrier (2004-01-3526) Bielenberg, R., Faller, R., et al.

Crash Protection of Stock Car Racing Drivers - Application of Biomechanical

Analysis of Indy Car Crash Research (2006-22-0016)

Melvin, J. W., Begeman, P. C., et al. 
Stock Car Racing Driver Restraint - Development and Implementation of Seat

Performance Specification (2008-01-2974) Patalak, J. P., and Melvin, J. W.

Examination of a Properly Restrained Motorsport Occupant (2013-01-0804)

Patalak, J. P., Gideon, T. W., and Melvin, J. W............................................ 151

About the Editors .......................................................................................................... 169 


\section{Acknowledgments}

Much of the work presented in this compendium is the result of significant support of those conducting the research by a number of individuals and their organizations. We would like to acknowledge the following individuals and their organizations.

Gary Dickinson, GM vice president of Technical Staffs, who, in 1992, recognized the need for better driver protection and had the insight to involve both GM Motorsports and GM Research Laboratories in a multidisciplinary approach to the problem.

Herb Fishel, director of GM Motorsports (retired), who provided manpower and support for racing safety research while at GM and continues to be a strong advocate for driver safety.

John Pierce, GM Motorsports, whose insights into the inner workings of motorsports and his knowledge of the best way to proceed allowed researchers to interface smoothly and successfully with racers and their teams.

Jim Hall, Chaparral Cars, who provided his state-of-the-art racecars for the fitting and evaluation of the first accident data recorders (ADRs) used in motorsports competition. His patience, understanding, and support were instrumental in the research that provided the basis for the current use of ADRs in racecars.
Steve Peterson, NASCAR R\&D Center, director of safety, for his skill at implementing the necessary technical improvements to make NASCAR's drivers among the safest in the world.

Sid Watkins, M.D., a pioneer in racing safety and trackside medicine, who, in 2004, formed the FIA Institute for Motorsports Safety and led significant efforts in racing safety research.

\section{SAE International Motorsports Engineering Conference and Exhibition-These meetings, with origins in the mid 1980s, became the international forum for academia, industry, and competitors to share motorsports technology data and opinion. Motorsports safety was a leading component of these conferences.}

